\section{JURNAL ABDIMAS

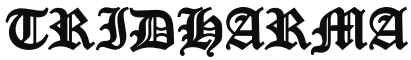

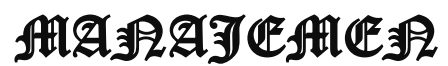

P-ISSN 2615-6849, E-ISSN 2716-070X

Jurnal ABDIMAS Vol.3,No.1,Desember 2021,Hal(110-114)

@ Prodi Manajemen Fakultas Ekonomi Universitas Pamulang

Email: abdimasjurnal.unpam@gmail.com Telp: (021) 741-2566

\title{
PENGELOLAAN KEUANGAN YANG EFEKTIF DAN EFISIEN PADA KELURAHAN BENDA BARU
}

\author{
Angga Pratama, Bambang Purnomo Yanuarso, M. Gandung, Aria Aji Priyanto, Supardi. \\ Dosen Prodi Manajemen Fakultas Ekonomi Universitas Pamulang \\ Email : dosen02155@unpam.ac.id,dosen02142@unpam.ac.id, dosen02020@unpam.ac.id, \\ dosen01048@unpam.ac.id, dosen00491@unpam.ac.id
}

\begin{abstract}
ABSTRAK
Tujuan dari kegiatan Pengabdian Kepada Masyarakat adalah untuk melaksanakan salah satu Tri Darma Perguruan Tinggi. Selain itu diharapkan dengan pengabdian kepada masyarakat tersebut keberadaan perguruan tinggi dapat memberikan kontribusi besar kepada pengembangan dan penerapan keilmuan kepada masyarakat. Metode yang digunakan pada Pengabdian Kepada Masyarakat ini berupa penyampaian materi secara verbal dan pembelajaran yang menekankan pada proses memaksimalkan secara efektif dan efisien dalam meningkatkan pengelolaan pada organisasi karang taruna (PKK Kelurahan Benda Baru).

Memanfaatkan strategi pemasaran guna meningkatkan kreatifitas, keterampilan, pendapatan agar mampu meningkatkan pendaptan atau value baik untuk keluarga dan negara.. Hal ini menjadi bahan untuk pengabdian kepada masyarakat di kelurahan Pamulang Barat yang dilaksanakan selama tiga hari. Namun sebelum melaksanakannya, kami sudah melakukan beberapa kali kunjungan yang bertujuan agar kami bisa survey dan melaksanakan pengabdian kepada masyarakat dengan baik.

Oleh sebab itu, kami mengambil judul Pengelolaan Keuangan Yang Efektif dan Efisien pada Kelurahan Benda Baru.
\end{abstract}

Kata kunci : Pengelolaan Keuangan.

\section{ABSTRACT}

The purpose of Community Service activities is to carry out one of the Tri Dharma of Higher Education. In addition, it is hoped that with community service, the existence of universities can make a major contribution to the development and application of science to the community. The method used in this Community Service is in the form of verbal delivery of material and learning that emphasizes the process of maximizing PAD effectively and efficiently in improving the management of youth organizations (PKK Kelurahan Benda Baru).

Utilizing marketing strategies to increase creativity, skills, income in order to be able to increase income or value for both family and country. This became material for community service in the West Pamulang village which was carried out for three days. However, before implementing it, we have made several visits with the aim that we can survey and carry out community service well. Village.

Therefore, we took the title of Effective and Efficient Financial Management at Benda Baru

\section{Keywords: Financial Management.}




\section{JURNAL ABDIMAS

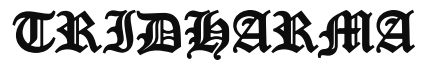

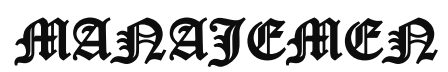

P-ISSN 2615-6849, E-ISSN 2716-070X

Jurnal ABDIMAS Vol.3,No.1,Desember 2021,Hal(110-114)

$@$ @rodi Manajemen Fakultas Ekonomi Universitas Pamulang

Email: abdimasjurnal.unpam@gmail.com Telp: (021) 741-2566 


\section{JURNAL ABDIMAS

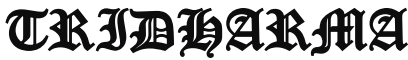

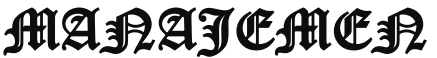

P-ISSN 2615-6849, E-ISSN 2716-070X

Jurnal ABDIMAS Vol.3,No.1,Desember 2021,Hal(110-114)

@ Prodi Manajemen Fakultas Ekonomi Universitas Pamulang

Email: abdimasjurnal.unpam@ gmail.com Telp: (021) 741-2566

\section{PENDAHULUAN}

Tugas

pendidikan

adalah

mengupayakan agar anak didik bisa mengenal potensi dirinya, sedangkan pendidikan berperan memberikan fasilitas agar mereka dapat mengembangkan potensinya, baik di bidang akademik maupun potensi non-akademik. Mengenai hal tersebut bagaimana upaya pendidikan dalam meningkatkan sumber daya manusia yang berkualitas. Sumber daya manusia yang tinggi dapat mempercepat pertumbuhan bangsa, agar menjadi sumaber daya yang maju dan produktif penduduk harus mempunyai kualitas yang memadai sehingga dapat menjadi modal pembangunan yang efektif khususnya kaum . Masalah yang dihadapi di Indonesia saat ini adalah masih banyaknya sumber daya manusia khususnya dalam pengembangan diri dalam segi usaha agar dapat meningkatkan kemampuan dan finansial keluarga. Dengan keterbatasan ekonomi keluarga saat ini, bagaimana kedepan Yayasan al Amienmemiliki nilai kualitas dan kuantitas secara bisnis yang baik sehingga dapat meningkatkan usaha mikro.

Dengan majunya dunia teknologi dan sistem informasi saat ini seyoganya dapat dimanfaatkan dengan baik oleh untuk meningkatkan daya saing terutama usaha mikro dalam berwirausaha. Tidak dapat dipungkiri saat ini wirausahawan masih didominasi oleh kaum laki-laki, sehingga waktunya ibu ibu PKK dapat berpartisipasi banyak dalam peningkatan usaha mikro yang secara nilai/value suatu usaha untuk menjual, memasarkan dan mencari segmen guna menjual produk barang dan jasa yang dihasilkan. Sehingga keberadaan UKM yang dirintis oleh sebagai ujung tombak kemajuan usaha mikro.

Sasaran yang ingin di capai melalui program pelatihan wirausaha adalah agar para PKK khususnya Yayasan al Amiendapat memanfaatkan strategi pemasaran ini guna meningkatkan kreatifitas, keterampilan, pendapatan agar mampu meningkatkan pendaptan atau value baik untuk keluarga dan negara.

communication) dimulai dari manajemen puncak kemudian mengalir kebawah sampai tingkat karyawan. Maksud komunikasi ini adalah untuk memberikan pengarahan, informasi, instruksi, nasehat/sasaran dan penilaian kepada bawahan serta memberikan kepada anggota organisasi tentang tujuan dan kebijakan organisasi. Kalau komunikasi keatas (upward communication) mempunyai fungsi untuk mensuplai informasi kepada tingkat manajemen tingkat atas tentang apa yang terjadi pada tingkat bawah. Hal ini dapat dipandang sebagai data atau informasi umpan balik bagi manajemen tingkat atas.

\section{RUMUSAN MASALAH}

Dengan mempertimbangkan latar belakang yang telah diutarakan diatas kami berinisiatif untuk membentuk pengabdian masyarakat bagi para karang taruna melalui pelatihan pemanfaatan pengelolaan . Agar kualitas dan kuantitas kelurahan Pamulang Baratdapat memanfaatkan teknologi guna meningkatkan pendapatan daerah kreatifitas, keterampilan, pendapatan agar mampu bersaing dengan produk usaha lainnya.

\section{TUJUAN KEGIATAN}

Adapun tujuan dari pada PKM (Pengabdian Kepada Masyarakat) ini adalah:

1. Memberikan Penyuluhan kepada PKK

2. Memberikan pengetahuan mengenai Pengelolaan Keuangan

3. Manajemen resiko

\section{TINJAUAN PUSTAKA}

Pemberdayaan Fakir Miskin merupakan komitmen bersama seluruh komponen bangsa, baik pemerintah maupun masyarakat. Paradigma pemberdayaan dalam pengentasan fakir miskin merupakan pergeseran cara pandang terhadap fakir miskin sebagai obyek pembangunan selama ini. Ditengah segala keterbatasannya, kita semua menyadari bahwa Fakir Miskin adalah juga manusia yang memiliki berbagai 


\section{JURNAL ABDIMAS

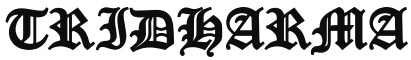 AtA}

P-ISSN 2615-6849, E-ISSN 2716-070X

Jurnal ABDIMAS Vol.3,No.1,Desember 2021,Hal(110-114)

@ Prodi Manajemen Fakultas Ekonomi Universitas Pamulang

Email: abdimasjurnal.unpam@ @mail.com Telp: (021) 741-2566 potensi untuk dapat dikembangkan dan diberdayakan, paling tidak "agar mereka dapat menolong diri mereka sendiri", sebagaimana prinsip yang sering dikembangkan dalam pembangunan kesejahteraan sosial.

Solidaritas sosial yang tinggi, mobilitas yang tinggi, keuletan, dan orientasinya kemasa depan yang cukup kuat, merupakan diantara sekian potensi yang masih dimiliki oleh Fakir Miskin. Implementasinya tentu disesuaikan dengan kondisi daerahnya masing-masing. Karena berdasarkan wilayahnya, program pemberdayaan fakir miskin dikonsentrasikan berdasarkan karakteristik yang terbagi kedalam: wilayah hutan kemasyarakatan, wilayah pedesaan (termasuk daerah pertanian dan pegunungan), wilayah desa-kota (sub urban, termasuk kawasan industri), wilayah perkotaan, wilayah pesisir/pantai, wilayah kepulauan terpencil, wilayah perbatasan antarnegara, wilayah eks korban bencana alam, dan wilayah eks korban bencana sosial.

Seiring dengan upaya-upaya pemberdayaan masyarakat dalam pembangunan kesejahteraan sosial, maka program pemberdayaan fakir miskin juga merupakan bagian yang tidak terpisahkan dari pemberdayaan potensi sumber kesejahteraan sosial yang ada dimasyarakat, diantaranya Karang Taruna. Karang Taruna adalah organisasi sosial wadah pengembangan generasi muda yang tumbuh dan berkembang atas dasar kesadaran dan tanggungjawab sosial dari, oleh, dan untuk masyarakat terutama generasi muda di desa/kelurahan atau komunitas adat sederajat yang bergerak dibidang usaha kesejahteraan sosial. Sebagai social institution yang menjadi sumberdaya sosial paling potensial di masyarakatnya, Karang Taruna diorientasikan untuk menjadi organisasi pelayanan kemanusiaan penyelenggara Usaha Kesejahteraan Sosial yang memiliki pendekatan dan standar pada pendekatan pekerjaan sosial yang memadai, karena Karang Taruna adalah juga Volunteer.

Untuk itulah, untuk menjadikan Karang Taruna sebagai organisasi atau kelompok masyarakat fungsional yang secara khusus membantu pemerintah dalam programprogram kesejahteraan sosial seperti pemberdayaan fakir miskin, maka peran Karang Taruna juga lebih diarahkan pada kegiatan-kegiatan advokasi, bimbingan, dan pendampingan terhadap implementasi program pemberdayaan fakir miskin. Hal itu juga mengingat keberadaan Karang Taruna yang tumbuh dan berkembang dihampir seluruh desa/kelurahan di Indonesia baik wilayah pedesaan, pesisir, hutan kemasyarakatan, industri, maupun eks korban bencana. Berikut ini beberapa istilah yang berhubungan dengan implementasi Karang Taruna :

1. Pemberdayaan Masyarakat adalah upaya mengembangkan potensi dan kapasitas masyarakat agar mereka dapat mengatasi ataupun menangani dengan baik permasalahan ataupun tantangan kehidupan yang sedang ataupun akan mereka alami.

2. Usaha Kesejahteraan Sosial (UKS) adalah serangkaian kegiatan yang ditujukan untuk mengatasi masalah sosial atau kerawanan sosial ekonomi dari anggota masyarakat melalui peningkatan kemampuan sumberdaya manusia dan peningkatan akses terhadap pelayanan sosial dasar dengan mendayagunakan sumbersumber sosial yang ada di masyarakat.

3. Fakir Miskin adalah orang yang sama sekali tidak mempunyai sumber mata pencaharian dan tidak mempunyai kemampuan memenuhi kebutuhan pokok yang layak bagi kemanusiaan atau orang yang mempunyai sumber mata pencaharian tetapi tidak dapat memenuhi kebutuhan pokok yang layak bagi kemanusiaan (PP 42/1981).

4. Usaha Ekonomis Produktif (UEP) adalah serangkaian kegiatan yang ditujukan untuk meningkatkan 


\section{JURNAL ABDIMAS

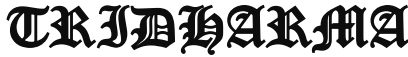

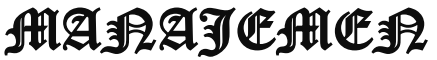

P-ISSN 2615-6849, E-ISSN 2716-070X

Jurnal ABDIMAS Vol.3,No.1,Desember 2021,Hal(110-114)

@ Prodi Manajemen Fakultas Ekonomi Universitas Pamulang

Email: abdimasjurnal.unpam@ gmail.com Telp: (021) 741-2566 kemampuan dalam mengakses sumber daya ekonomi, meningkatkan kemampuan usaha ekonomi, meningkatkan produktivitas kerja, meningkatkan penghasilan dan menciptakan kemitraan usaha yang saling menguntungkan.

5. Kewirausahaan adalah suatu usaha bisnis ekonomi berdasarkan tujuan dan sistematika tertentu yang dimulai dengan skala usaha kecil dan dengan menggunakan analisis "peluang", konseptual, inovasi, dan mengarah pada pemberian contoh berdasarkan falsafah kepemimpinan.

6. Pendamping adalah seorang, sekelompok orang atau kumpulan orang dalam lembaga yang memiliki kompetensi di bidang usaha kesejahteraan sosial dan usaha ekonomis produktif melalui program peningkatan kemampuan ekonomi yang meningkatkan taraf kesejahteraan sosial masyarakat.

7. Pendampingan sosial adalah proses menjalin relasi sosial antara pendamping dengan kelompok masyarakat yang tergabung dalam program tertentu dan masyarakat sekitarnya dalam rangka memecahkan masalah, memperkuat dukungan, mendayagunakan berbagai sumber dan potensi dalam pemenuhan kebutuhan hidup, serta meningkatkan akses anggota masyarakat terhadap pelayanan sosial dasar dan fasilitas pelayanan publik lainnya.

Dengan paradigma pembangunan saat ini yang menempatkan manusia sebagai sumberdaya potensial, maka sesungguhnya pembangunan menghadapi tantangan nyata dalam bentuk upaya-upaya konstruktif kearah pemberdayaan sumberdaya potensial tersebut untuk menjadi sumberdaya yang aktual dan konkrit. Umumnya masyarakat kita di desa/kelurahan adalah sumber daya manusia yang memiliki kemampuan dan ketrampilan mengelola sumber daya alam,modal, dan teknologi, disamping sebagian lainnya juga memiliki kemampuan untuk memimpin dan mengorganisir

\section{METODE PELAKSANAAN}

Metode kegiatan yang digunakan adalah kita kunjungan langsung ke PKK kelurahan Benda Baru akan memberikan pelatihan disana pada tanggal 22- 24 Okotber 2020. Pelatihan ini bertujuan agar para karang taruna mengenal pelatihan memaksimalkan secara efektif dan efisien dalam meningkatkan pengelolaan.

\section{HASIL DAN PEMBAHASAN}

Pengabdian Masyarakat (LPPM) Universitas Pamulang yang dilakukan oleh dosen-dosen program studi Manajemen telah berjalan dengan lancar dan mendapat sambutan hangat dari tempat pelaksanaan kegiatan ini

Harapan kami dengan pengabdian ini dapat membuka wawasan masyarakat yang diperoleh adalah bertambahnya keilmuan bagi para Para Masyarakat dan Ilmu yang diperoleh pada Pengabdian Masyarakat kali ini diharapkan mampu memberikan semangat baru bagi kita dalam menyampaikan materi dan motivasi serta berkontribusi bagi generasi muda, baik dilingkungan sekolah, kampus dan keluarga

\section{KESIMPULAN DAN SARAN Kesimpulan}

Kegiatan PKM yang dilaksanakan di Kel. Benda Baru Kec. Pamulang Kota Tangerang Selatan berjalan sesuai dengan apa yang diharapkan, dimana para peserta bisa mendapatkan input dari materi-materi yang disampaikan narasumber.

\section{Saran}

Pelaksanaan kegiatan Pengabdian Kepada Masyarakat oleh Lembaga Penelitian dan Pengabdian Masyarakat (LPPM) Universitas Pamulang yang dilakukan oleh dosen-dosen Program Studi Manajemen 


\section{JURNAL ABDIMAS

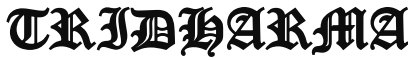 \\ AtA:}

P-ISSN 2615-6849, E-ISSN 2716-070X

Jurnal ABDIMAS Vol.3,No.1,Desember 2021,Hal(110-114)

@Prodi Manajemen Fakultas Ekonomi Universitas Pamulang

Email: abdimasjurnal.unpam@ gmail.com Telp: (021) 741-2566 telah berjalan dengan lancar dan mendapat sambutan positif dari Pak Lurah dan Anggota Kelurahan Karang Taruna Benda Baru. Harapan kami selaku dosen dengan adanya kegiatan PKM ini dapat menambah ilmu yang bermanfaat dalam hal sikap disiplin dan tanggung jawab.

1. Melihat respon dari kegiatan PKM yang dilakukan di Kel. Benda Baru Kec. Pamulang Kota Tangerang Selatan ini, kegiatan PKM sepatutnya masih difokuskan pada ibu-ibu PKK dan pelaku UMKM.

2. Kegiatan PKM pada Karang Taruna hendaknya masih difokuskan pada materi-materi yang terkait dengan strategi pemasaran new era pandemic covid 19.

\section{DAFTAR PUSTAKA}

Arikunto, Suharsimi. 2008. Dasar-Dasar Evaluasi Pembelajaran. Jakarta: Bumi Aksara. 308 hlmn.

A.M. Sardiman, 2001. Interaksi dan Motivasi Belajar Mengajar. Jakarta: Raja GrafindoPersada. 224 hlmn.

Kartini Kartono, 2008, Pemimpin dan kepemimpinan. Jakarta: Raja Grafindo Persada

Pasaribu, V. L. D., Agrasadya, A., Shabrina, N., \& Krisnaldy, K. (2020). Menjadi Enterpreneur Muda Yang Memiliki Jiwa Leadership Untuk Menghadapi Masa Depan. Abdi Laksana: Jurnal Pengabdian Kepada Masyarakat, 1(1).

Pasaribu, V. L. D., Susanti, F., \& Hartuti, E. T. K. (2019). Memotivasi Siswa dan Siswi SMK Letris Indonesia di Dalam Menentukan Pilihan Untuk Melanjutkan Pendidikan Atau Bekerja Setelah Lulus Sekolah. Jurnal Pengabdian Dharma Laksana, 1(2), 161-172.
Pasaribu, V. L. D., Sulaiman, S., Sutiman, S., Thaharudin, T., \& Purnomo, B. Y. (2020). Pengenalan Letak Posyandu Terdekat Dikelurahan Pisangan Dengan Manajemen Pemasaran Revolusi 4.0 Untuk Meningkatkan Pengetahuan Masyarakat Letak Dan Fungsi Posyandu Terdekat Pada Kelurahan Pisangan. Dedikasi Pkm, 1(1), 105110.

Pasaribu, V. L. D., Oktrima, B., Prabowo, B., Arianto, N., \& Haryoko, U. B. (2020). Progam Pendamp 1 Dan Penyelenggaraan Pendid Anak Pada Usia Dini Terhadap Prestasi Belajar Dilingkungan Rt $020 \mathrm{Rw}$ 009. Kel Giri Peni. Kec Wates. Yogyakarta. Jurnal Lokabmas Kreatif, 1(1), 71-75.

Pasaribu, V. L. D., Jannah, M., Fazar, M., Putra, S. P., Monalisa, M., \& Sofa, M. (2021). MENINGKATKAN PRODUKTIVITAS USAHA DIMASA PANDEMI PADA IBU PKK RT 004/003 KELURAHAN SAWAH BARU CIPUTAT, TANGERANG SELATAN. Abdi Laksana: Jurnal Pengabdian Kepada Masyarakat, 2(2), 295301.

Pasaribu, V. L. D., Yuniati, H. L., Pranata, R., Sembayu, R., Purba, S. M., \& Nurbayani, T. T. A. (2021). MANAJEMEN KEUANGAN UNTUK MENGHADAPI DAN BERTAHAN DI ERA COVID 19. Jurnal Abdimas Tri Dharma Manajemen, 2(2), 12-18.

Pasaribu, V. L. D., Dwiyatni, A., Sabina, C., Ridwan, M., Gunawan, D. D., \& Noviani, B. C. (2021). EVALUASI PENERAPAN 3M DIMASA PANDEMIC COVID 19. Jurnal Abdimas Tri Dharma Manajemen, 2(2), 54-60.

Pasaribu, V. L. D., Syafei, A. N., Farhan, 


\section{JURNAL ABDIMAS

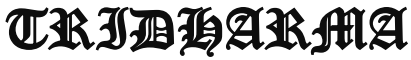

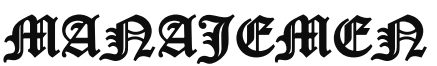

\section{P-ISSN 2615-6849, E-ISSN 2716-070X}

Jurnal ABDIMAS Vol.3,No.1,Desember 2021,Hal(110-114)

@Prodi Manajemen Fakultas Ekonomi Universitas Pamulang

Email: abdimasjurnal.unpam@gmail.com Telp: (021) 741-2566
A., Aufaizah, A., Irani, C., \& Firtiayani, S. R. (2021). PENGARUH DISPLIN PROTOKOL KESEHATAN TERHADAP PENCEGAHAN PENULARAN VIRUS COVID19. Jurnal Abdimas Tri Dharma Manajemen, 2(2), 91-98.

Pasaribu, V. L. D., Septiani, F., Rahayu, S., Lismiatun, L., Arief, M., Juanda, A., ... \& Rahim, R. (2021). Forecast Analysis of Gross Regional Domestic Product based on the Linear Regression Algorithm Technique.

Priadi, A., Pasaribu, V. L. D., Virby, S., Sairin, S., \& Wardani, W. G. (2020). Penguatan Ekonomi Kreatif Berbasis Sumber Daya Desa Dikelurahan Rempoa. Abdi Laksana: Jurnal Pengabdian Kepada Masyarakat, 1(3), 356-35

Pasaribu, V. L. D., Priadi, A., Anismadiyah, V., Rahayu, S., \& Maduningtias, L. (2021). PENYULUHAN KREATIF DAN INOVATIF MENINGKATKAN MUTU PRODUKSI UMKM DI DESA BELEGA KABUPATEN GIANYAR. Pro Bono Jurnal Pengabdian Kepada Masyarakat, 1(02).

Pasaribu, V. L. D. (2021). PELATIHAN BERBASIS ONLINE DI ERA COVID-19. Jurnal Abdimas Tri Dharma Manajemen, 2(3), 26-32.

Pasaribu, V. L. D., \& Setyowati, R. (2021). ADAPTASI KEHIDUPAN NEW
NORMAL PADA MASA
PANDEMI COVID-19
DIYAYASAN PONDOK
PESANTREN DAN PANTI
ASUHAN NURUL IKHSAN
KECAMATAN SETU, KOTA
TANGERANG SELATAN. Jurnal
Lokabmas Kreatif: Loyalitas
Kreatifitas Abdi Masyarakat
Kreatif, 2(2), 82-88.

Prijosaksono, Aribowo dan Sri Bawono.2005. The Power of Entrepreneurial

Intelligence,Membangun Sikap dan Perilaku Entrepreneur Dalam Diri Anda.Elex Media Komputindo, Jakarta

\section{DOKUMENTASI KEGIATAN}
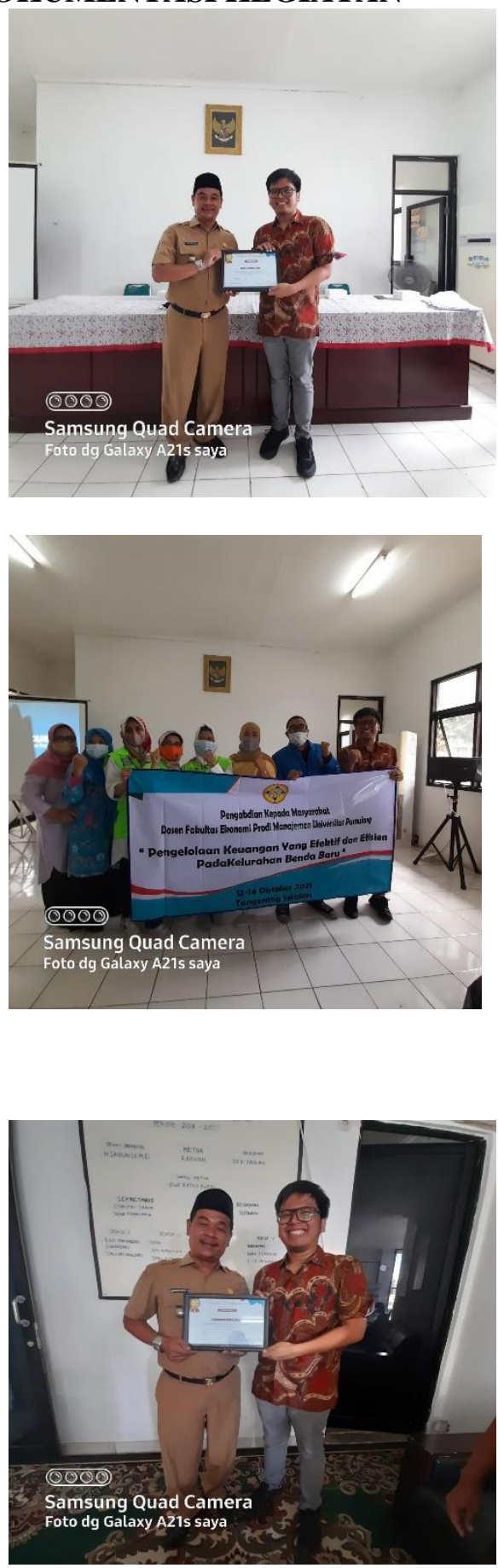